Sains Malaysiana 47(6)(2018): 1259-1268

http://dx.doi.org/10.17576/jsm-2018-4706-22

\title{
Proteomic Analysis of Stored Core Oil Palm Trunk (COPT) Sap Identifying Proteins \\ Related to Stress, Disease Resistance and Differential Gene/Protein Expression
}

(Analisis Proteomik Pengenalpastian Protein Sap Teras Batang Kelapa Sawit (TBKS) Tersimpan Berkaitan Tekanan, Pertahanan Penyakit dan Perbezaan Pengekspressan Gen/Protein)

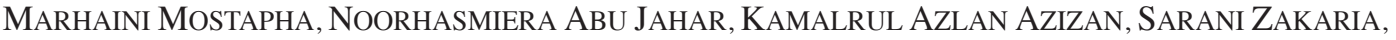 \\ WAN MOHD AIZAT \& SHARIFAH NABIHAH SYED JAAFAR*
}

\begin{abstract}
Oil palm is the major crop grown and cultivated in various Asian countries such as Malaysia, Indonesia and Thailand. The core of oil palm trunk (COPT) consists of high sugar content, hence suitable for synthesis of fine chemicals and biofuels. Increase of sugar content was reported previously during prolonged COPT storage. However, until now, there has been no report on protein profiles during storage. Therefore, in this study, protein expression of the COPT during the storage period of one to six weeks was investigated using sodium dodecyl sulphate polyacrylamide gel electrophoresis (SDS-PAGE) coupled with optical density quantification and multivariate analyses for measuring differentially expressed proteins. Accordingly, protein bands were subjected to tryptic digestion followed by tandem mass spectrometry (nanoLC$M S / M S$ ) protein identification. The results from SDS-PAGE showed consistent protein bands appearing across the biological replicates ranging from 10.455 to $202.92 \mathrm{kDa}$ molecular weight $(\mathrm{MW})$ regions. The findings from the principal component analysis (PCA) plot illustrated the separation pattern of the proteins at weeks 4 and 5 of storage, which was influenced mainly by the molecular weights of 14.283, 25.543, 29.757, 30.549, 31.511, 34.585 and $84.395 \mathrm{kDa}$, respectively. The majority of these proteins are identified as those involved in stress-and defense-related, disease resistance, as well as gene/protein expression processes. Indeed, these proteins were mostly upregulated during the later storage period suggesting that long-term storage may influence the molecular regulation of COPT sap.
\end{abstract}

Keywords: Densitometry analysis; Elaeis guineensis; LC-MS; principal component analysis; SDS-PAGE

ABSTRAK

Kelapa sawit merupakan antara tanaman utama di negara Asia seperti Malaysia, Indonesia dan Thailand. Teras batang kelapa sawit (TBKS) mempunyai kandungan gula yang tinggi, maka ia sesuai digunakan untuk penghasilan bahan kimia ringkas dan bahan bakar bio. Peningkatan kandungan gula pada sap daripada TBKS yang disimpan telah dilaporkan. Walau bagaimanapun, setakat ini, kajian terhadap perubahan profil protein TBKS semasa penyimpanan masih belum diterokai. Maka dalam kajian ini, pengekspresan protein TBKS yang tersimpan selama satu hingga enam minggu telah dikaji menggunakan gel elektroforesis $1 D$ (SDS-PAGE) ditambah dengan penentuan ketumpatan optik dan analisis multivariat untuk mengukur jalur protein yang berbeza. Jalur protein ini kemudiannya dipotong menggunakan tripsin diikuti dengan pengenalpastian protein menggunakan spektrometri jisim (nanoLC-MS/MS). Keputusan daripada SDS-PAGE menunjukkan jalur protein yang konsisten merentasi replikasi biologi dengan berat molekul protein daripada 10.455 kepada 202.92 kDa. Keputusan analisis prinsipal komponen utama (PCA) menunjukkan corak pemisahan protein pada minggu ke-4 dan minggu ke-5 penyimpanan dipengaruhi oleh berat molekul 14.283, 25.543, 29.757, 30.549, 31.511, 34.585 dan 84.395 kDa. Majoriti protein yang dikenal pasti merupakan protein yang terlibat dengan tekanan dan pertahanan, protein yang berkaitan dengan perintang penyakit, serta proses pengekspressan gen atau protein. Penambahan tempoh penyimpanan telah menyebabkan protein ini dikawal naik sekaligus mencadangkan kesan tempoh penyimpanan mempengaruhi kawal atur eskpresi molekul protein sap TBKS.

Kata kunci: Analisis densitometri; analisis kumpulan utama; Elaeis guineensis; LC-MS; SDS-PAGE

\section{INTRODUCTION}

Oil palm Elaeis guineensis Jacq is one of the most highly valued and profitable plantation crops grown. Malaysia is heavily reliant on the oil palm industry as it contributes significantly to the economic growth of the country, accounting for $46.9 \%$ of the total agricultural sector in gross domestic product (GDP) (Department of Statistic
Malaysia 2016). However, after the plantation period between 20 and 25 years, the oil palm trees are logged, thereby, contributing up to 8.2 million tonnes of oil palm trunk (OPT) biomass residing in the field underutilised (MPOB 2016). Consequently, this phenomenon has led to greenhouse gas (GHG), due to the release of carbon dioxide $\left(\mathrm{CO}_{2}\right)$ and methane $\left(\mathrm{CH}_{4}\right)$ into the atmosphere through 
the decomposition of dead plant biomass and soil organic matter (Smith et al. 2014). Accordingly, the biomass, as a by-product, should be utilised for other applications to generate potential revenues. OPT sap is reported to contain a high amount of free sugars, other than proteins and organic acids (Yamada et al. 2010). These sugars can be converted into valuable compounds such as bioethanol/biofuel (Bukhari et al.2017), 5-hydroxymethylfurfural (Mostapha et al. 2016) and methyl levulinate (Jahar et al. 2017).

Proteomics is an important approach adopted for the investigation and examination of overall protein compositions in organisms (Hood et al. 2013). Notwithstanding, there are three preferred methods for the separation of complex protein or peptide samples in proteomics, including denaturing polyacrylamide gel electrophoresis (PAGE), or sodium dodecyl sulphate polyacrylamide gel electrophoresis (SDS-PAGE), twodimensional gel electrophoresis and high-performance liquid chromatography (HPLC). Moreover, other useful tools include capillary electrophoresis and affinity chromatography (Desiderio et al. 2010; Hage et al. 2012). SDS-PAGE is a preferred technique for protein separation mainly due to its simplicity, reproducibility, as well as acceptable instrumentation and consumable costs. Also, this method (initially described by Laemmli in 1970) separates proteins based on their primary structure or sizes. Moreover, SDS-PAGE can be used to check the purity of samples and to estimate their molecular weights for unknown proteins.

Several proteomics studies by other researchers have used various parts of the oil palm tree as the basis for their work. A study by Al-Obaidi et al. (2014) identified the alteration of protein abundance in oil palm infected with Ganoderma boninense. In a separate study, de Carvalho Silva et al. (2014) reported differentially expressed proteins during the acquisition of somatic embryogenesis in oil palm (Elaeis guineensis Jacq.). Jeffery Daim et al. (2015) in their study, compared the protein profile of oil palm leaves infected with Ganoderma boninense, which showed changes in proteins involved in photosynthesis, carbohydrate metabolism, immunity and defense. Notably, the previous studies indicated protein changes in response to either biological or environmental factors, which focused on proteins related to growth and disease, respectively. However, the different protein expression level can also influence the elevation of sugar content in the core oil palm trunk (СОРТ) upon storage. Indeed, the understanding of the specific molecular regulation of the COPT, particularly, the protein profiles during storage remains inadequate, thereby providing an important if not fundamental basis to understand the biological system of the COPT to different storage conditions and stresses.

The metabolomics study by Mostapha et al. (2017) reported the increase of sugars and organic acids in the sap of stored COPT. Interestingly, the proteins and enzymes related to carbohydrate metabolism and synthesis may have been activated upon by a stress condition. Notwithstanding, these protein profiles are therefore considered important to identify the responsible proteins towards the increment of metabolites as observed. Moreover, this study aimed to compare the proteome profiles of COPT during storage. Accordingly, the analysis was performed on the sap of stored COPT, for a period of one to six weeks, at a temperature of $10^{\circ} \mathrm{C}$. SDS-PAGE was performed to visualise the protein bands, followed by principal component analysis (PCA) of protein band densities to identify significantly expressed proteins. As the stored COPT is potentially incorporated for various applications such as biological catalysts, the functional characterisations of the proteins are therefore crucial.

\section{MATERIALS AND METHODS}

\section{MATERIALS}

The acetone, acetonitrile, methanol and glacial acetic acid were purchased from Merck, Germany and the ammonium persulphate (APS), 1.5 M Tris-HCI (pH8.8) and 0.5 M Tris-HCI (pH6.8) buffers were purchased from Bio-Rad, USA. Phenol (pH8) was obtained from Amresco, USA. The N, N, N', N'-tetramethylethylenediamine (TEMED), trichloroacetic acid, ammonium acetate, ammonium bicarbonate, trypsin, Bradford reagent, bovine serum albumin (BSA), 30\% bis-acrylamide, and Coomassie Brilliant Blue (CBB) R-250 were purchased from Sigma Aldrich, USA. Finally, the BLUeye prestained protein ladder was purchased from GeneDireX, China.

\section{SAMPLE PREPARATION}

In this study, the centre part of a 29-year-old OPT (Elaeis guineensis), was obtained from Leong Brothers Earthworks Construction, Kluang, Johor (N143'39.3”, E10341'38.4"). The COPT was wrapped and stored at $10^{\circ} \mathrm{C}$ for one week (W1), 2 weeks (W2), 3 weeks (W3), 4 weeks (W4), 5 weeks (W5) and 6 weeks (W6), separately. Once the sample reached its storage period, the COPT was pressed using a lab-scale machine, to collect their sap and stored at $-40^{\circ} \mathrm{C}$. Similarly, a fresh COPT without the storage treatment was also prepared. All samples were subjected to freeze-drying before protein extraction.

\section{TOTAL PROTEIN EXTRACTION AND DETERMINATION}

Protein extraction using the hybrid technique, as carried out by Wang et al. (2006) was performed along with several modifications using trichloroacetic acid (TCA), acetone and phenol extractions. Briefly, $100 \mathrm{mg}$ of the freezedried samples were mixed with $1 \mathrm{~mL} 10 \%$ TCA: acetone $(1: 1)(\mathrm{v} / \mathrm{v})$ and rotated at $16,000 \mathrm{rpm}$ for $3 \mathrm{~min}$ at $4^{\circ} \mathrm{C}$. The protein pellet was next added with a $1 \mathrm{~mL}$ mixture of $80 \%$ methanol: $0.1 \mathrm{M}$ ammonia acetate $(1: 1)(\mathrm{v} / \mathrm{v})$ and centrifuged at $16,000 \mathrm{rpm}$ for $3 \mathrm{~min}$ at $4^{\circ} \mathrm{C}$, before washing the pellet with $1 \mathrm{~mL}$ of $80 \%$ acetone, centrifuged at 16,000 rpm for $3 \mathrm{~min}$ at $4^{\circ} \mathrm{C}$ and left to air-dry for $10 \mathrm{~min}$ at room 
temperature. Next, a $600 \mu \mathrm{L}$ mixture of phenol: SDS buffer ratio $(1: 1)(\mathrm{v} / \mathrm{v})$, was added to the dried protein pellet, vortexed for $30 \mathrm{~s}$, before incubating at room temperature for $5 \mathrm{~min}$, followed by centrifuging at $16,000 \mathrm{rpm}$ for 5 min at $4^{\circ} \mathrm{C}$. The phenol phase containing the soluble proteins (top layer) was then mixed with $1.5 \mathrm{~mL} 80 \%$ methanol: $0.1 \mathrm{M}$ ammonia acetate $(1: 1)(\mathrm{v} / \mathrm{v})$ and stored at $-20^{\circ} \mathrm{C}$ overnight for protein precipitation. Accordingly, the samples were centrifuged at $16,000 \mathrm{rpm}$ for $5 \mathrm{~min}$ at $4^{\circ} \mathrm{C}$. The supernatants were then, carefully removed, leaving only white protein pellets and washed with $1 \mathrm{~mL}$ of 100 $\%$ methanol, followed by $1 \mathrm{~mL} 80 \%$ acetone solution. The protein pellets were next, air-dried at room temperature for $15 \mathrm{~min}$ and resuspended in $60 \mu \mathrm{L}$ of rehydration buffer (0.015 $\mathrm{M}$ urea and $0.5 \mathrm{mM}$ ammonium bicarbonate). The total protein concentration was determined using a Bradford Protein Assay Kit (Bio-Rad, USA) and quantified using a spectrophotometer at an absorbance wavelength of $595 \mathrm{~nm}$.

\section{SODIUM DODECYL SULFATE POLYACRYLAMIDE GEL ELECTROPHORESIS}

SDS-PAGE was performed according to Hashemi et al. (2016). The separating gel (12.50\%) was prepared with a mixture of $30 \%$ acrylamide/bis, $1.5 \mathrm{M}$ Tris-HCI (pH8.8), $10 \%(\mathrm{w} / \mathrm{v})$ APS, $10 \%$ SDS, deionised water and TEMED. Stacking gel was then prepared with a mixture of $30 \%$ acrylamide solution, $0.5 \mathrm{M}$ Tris-HCI (pH6.8), 10\% APS, $10 \%$ SDS, deionised water and TEMED. The samples were mixed with blue protein loading dye and the protein amount loading was fixed to $10 \mu \mathrm{g}$. A volume of $2 \mu \mathrm{L}$ of pre-stained protein ladder was used. The protein separation system was set to $75 \mathrm{~V}$ for $25 \mathrm{~min}$, followed by $125 \mathrm{~V}$ for $1 \mathrm{~h}$. Once completed, the gel was removed from the glass slip before staining.

\section{COOMASSIE BLUE DYE STAINING AND PROTEIN BAND ANALYSIS}

The gels were incubated in CBB staining solution overnight with gentle agitation. The gels were then transferred into a destaining solution (containing 10\% acetic acid and $40 \%$ methanol), applying gentle agitation for one hour, until the background of the gel was thoroughly destained, and replaced with distilled water for further background removal. Subsequently, the stained gel was scanned using a densitometer (Bio-rad, Hercules, CA) and each protein band was analysed, and its protein optical density (OD) quantified, using Quantity One Software (Bio-rad, Hercules, CA). Differentially expressed protein bands were then selected based on statistical analysis.

\section{STATISTICAL ANALYSIS}

The PCA was performed by exporting the protein density data into Soft Independent Modelling of Class Analogy (SIMCA)-P (version 11.0, Unimetrics AB, Umea, Sweden) to identify the protein bands able to be differentiated from among the treatment samples. The desired molecular weights (MWs) were filtered based on the samples showing the farthest separation in both score and loading plot, compared to control (fresh), with the variable importance projection (VIP) value $>1$. Subsequently, the one-way analysis of variance (ANOVA) with Tukey's post-test was performed using GraphPad InStat software, version 3.00 (San Diego California USA) to determine the significantly different proteins regarding the different storage periods (Figure 3 ). The $P$-values $<0.05,<0.01$ and $<0.001$ were considered significant.

\section{TRYPSIN DIGESTION AND PEPTIDE IDENTIFICATION BY NANOLC-MS/MS}

The selected protein bands were excised $(1 \times 1 \mathrm{~mm}$ cubes), destained (50\% acetonitrile in $50 \mathrm{mM}$ ammonium bicarbonate $\left(\mathrm{NH}_{4} \mathrm{HCO}_{3}\right)$ and reduced $(10 \mathrm{mM}$ DTT in 100 $\left.\mathrm{mM} \mathrm{NH} \mathrm{HCO}_{3}\right)$. The samples were then incubated for $30 \mathrm{~min}$ at $60^{\circ} \mathrm{C}$. Next, alkylation was performed in the dark by adding $100 \mu \mathrm{L}$ of $55 \mathrm{mM}$ iodoacetamide (IAA) in $100 \mathrm{mM} \mathrm{NH}_{4} \mathrm{HCO}_{3}$ followed by incubation for $30 \mathrm{~min}$ at room temperature. The samples were then washed with $1 \mathrm{~mL}$ of $50 \% \mathrm{ACN}$ in $100 \mathrm{mM} \mathrm{NH}_{4} \mathrm{HCO}_{3}$ and rehydrated with $100 \mu \mathrm{L}$ of $100 \% \mathrm{ACN}$. The samples were dried using a vacuum concentrator for $10 \mathrm{~min}$ followed by digestion (Trypsin/LysineC in $50 \mathrm{mM} \mathrm{NH}_{4} \mathrm{HCO}_{3}$ ) and incubated at $37^{\circ} \mathrm{C}$ overnight. The resulting peptides were extracted with $100 \%$ and $50 \% \mathrm{ACN}$, and dried using a vacuum concentrator and dissolved in $0.1 \%$ formic acid. The samples were next desalted using zip-tip (Sigma-Aldrich, USA) before they were analysed using nanoLC-MS/MS analysis.

Peptide separation was performed using Thermo Scientific C18 columns (Acclaim ${ }^{\mathrm{TM}}$ PepMap RSLC, $75 \mu \mathrm{m}$ $\times 15 \mathrm{~cm}, 2 \mu \mathrm{m}, 100 \AA$ ) on the Thermo Scientific Dionex UltiMate 3000 autosampler series (Nano/Cap System NCS-3500RS and Nano/Cap Pump NCP-3200RS). Gradient elution was performed at $0.3 \mu \mathrm{L}$ min- 1 and $40^{\circ} \mathrm{C}$, using $0.1 \%$ formic acid (A) and a mixture of $20 \%$ distilled water, $80 \% \mathrm{ACN}$ and $0.08 \%$ formic acid (B). The total run time was 50 min with the injection volume of $1 \mu \mathrm{L}$. The gradient started at 5\% B (0-30 min); 45\% B (30-30.1 min), 90\% B (30.1-35 min), 95\% B (35-35.1 min) and 5\% B (35.1-50 min). High-resolution mass spectrometry was performed using a MicrOTOF QIII Bruker Daltonics using captive spray positive ionisation with the capillary voltage: 1600 $\mathrm{V}$; drying gas: $4 \mathrm{~L} / \mathrm{min}$ and a dry gas temperature of $150^{\circ} \mathrm{C}$. The mass range was collected from between the values of 50 to $3000 \mathrm{~m} / \mathrm{z}$. The accurate mass data of the molecular ions, provided by the TOF analyser, were processed using Compass Data Analysis software (Bruker Daltonik GmbH) before performing further analysis.

\section{DATAANALYSIS}

The MaxQuant software (http://www.biochem.mpg. de/5111795/maxquant) was used for data processing of the spectra and the database search. The parameters used were set to 0.2 Da fragment tolerance, two missed cleavages, 
variable oxidation (Met) and fixed modifications of carbamidomethyl (Cys). The NCBI-Prot ID 2669 of Elaeis Guineensis (African oil palm) protein database (https:// www.ncbi.nlm.nih.gov/genome/?term=elaeis+guinensis), was used to search against sample mass spectra for protein candidate identification. The protein list was further trimmed using the following criteria; having at least one peptide, containing more than one MS/MS count per peptide, as well having $>1 \%$ peptide sequence coverage.

\section{RESULTS AND DISCUSSION}

The protein concentration of the stored COPT was found ranging from 0.55 to $2.60 \mathrm{mg} / \mathrm{mL}$, which was lower compared to the fresh (control) sample $(4.80 \mathrm{mg} / \mathrm{mL})$, (Table 1), which could be due to the impact of prolonged storage towards protein stability. The electrophoretic profiles using SDS-PAGE of these samples are shown in Figure 1. The protein patterns were observed to be mostly consistent across three biological replicates (Supplementary Figure 1). Furthermore, the different molecular weight found for the protein bands ranged from 10.455 to $202.92 \mathrm{kDa}$ from W1 to W6 of storage.

The PCA was used as a tool to detect significant changes in the pattern, grouping, similarities and the differences of the protein bands in each sample (Figure 2 ). The score plot (Figure 2a) showed a sample location in a model component while the loading plot (Figure 2b) interpreted the relationship between the variables. The PCA score plot of protein OD also showed that the samples were well clustered together, implying high consistency between the biological replicates, as observed in the SDS-PAGE (Supplementary Figure 1). The score plot was also found to show that the clusters of W4 and W5 were further separated from the other samples (W1, W2, W3, W6 and control $(\mathrm{F}))$ which were nearer the plot centre. Therefore, this suggests that W4 and W5 were different in their protein profiles compared to the other storage weeks.

Furthermore, the loading plot (Figure 2b) illustrates that seven proteins $(25.543,30.549,31.511,14.283$, $29.757,34.585$ and $84.395 \mathrm{kDa}$ ) were the major contributors towards the separation of the W4 and W5 clusters. Indeed, the different OD of the protein bands was quantitatively measured and statistically analysed as shown in Figure 3. Protein levels (measured by OD) at $14.283,25.543,30.549$ and $34.585 \mathrm{kDa}$ fluctuated during COPT storage (W1-W6), observing a major increment at W4. Meanwhile, similar protein level was also seen across the storage period for proteins at $29.757 \mathrm{kDa}$, except for an incremental increase at W5. Notably, for proteins at $31.511 \mathrm{kDa}$, the highest OD was observed at W2. Interestingly, the MW $84.395 \mathrm{kDa}$ was only observed at W5 and W6 of storage. The identity of these seven protein bands was then determined using nanoLC-MS/ MS. Further protein analysis was performed, thereby leads to 13 protein candidates having at least one peptide, as detailed in materials and methods (Table 2).

Accordingly, two proteins were identified from MW $14.283 \mathrm{kDa}$ including phosphatase inhibitor 2 and uncharacterised protein LOC105041244. From MW $25.543 \mathrm{kDa}$, two proteins, receptor-like serine/ threonine-protein kinase SD1-8 and an uncharacterised protein LOC109506555 isoform X2 were identified. Likewise, from MW $29.757 \mathrm{kDa}$, tRNA (adenine (58)$\mathrm{N}$ (1))-methyltransferase non-catalytic subunit trm6

TABLE 1. Protein concentration of fresh (F) and stored COPT at week 1 (W1) until week 6 (W6). Values in mean \pm standard deviation

\begin{tabular}{lccccccc}
\hline Storage Periods & F & W1 & W2 & W3 & W4 & W5 & W6 \\
\hline Concentration $(\mathrm{mg} / \mathrm{mL})$ & $4.69 \pm 0.17$ & $0.94 \pm 0.01$ & $2.35 \pm 0.22$ & $1.31 \pm 0.02$ & $0.56 \pm 0.02$ & $0.79 \pm 0.02$ & $2.23 \pm 0.03$ \\
\hline
\end{tabular}

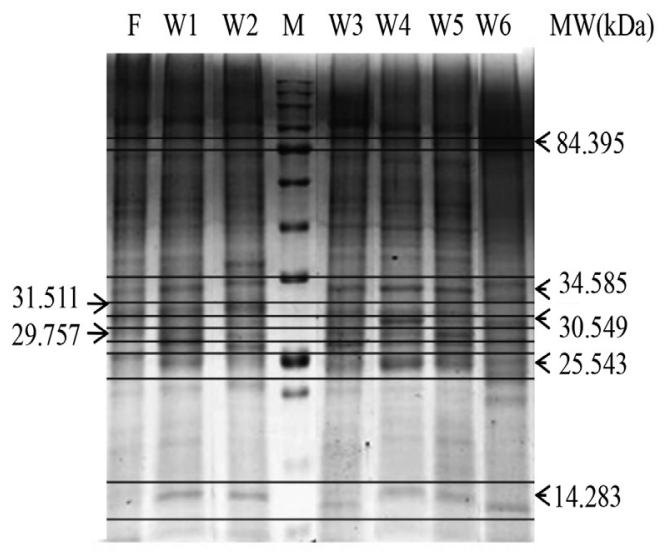

FIGURE 1. Representative SDS-PAGE lanes (from three biological replicates, Supplementary Figure 1) showing patterns of stored COPT sap total proteins from fresh (F) to Week 6 (W6) samples. The gel was stained with Coomassie blue and each lane was loaded an equal protein amount of $10 \mu \mathrm{g}$. M represent the protein marker 


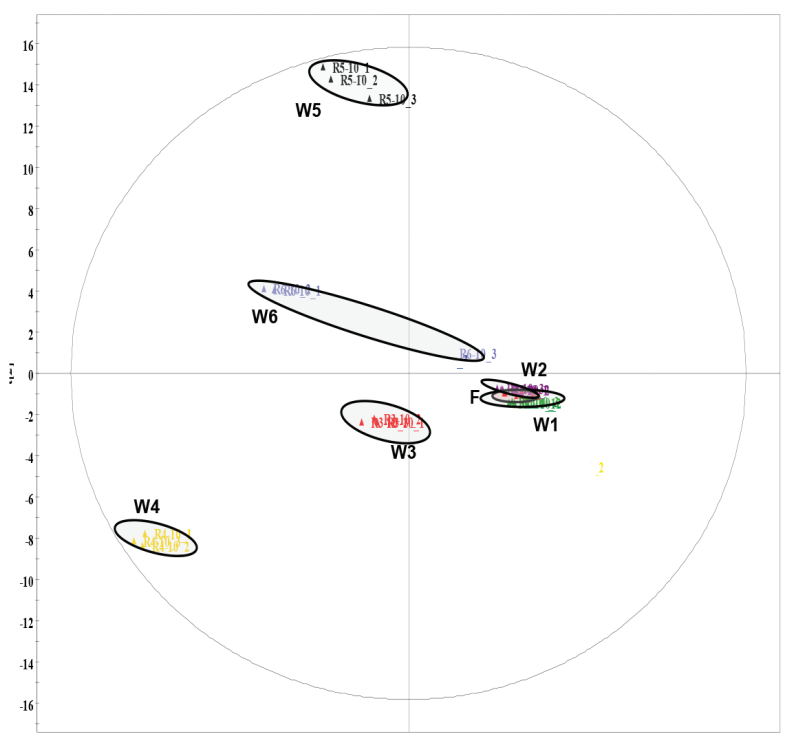

b

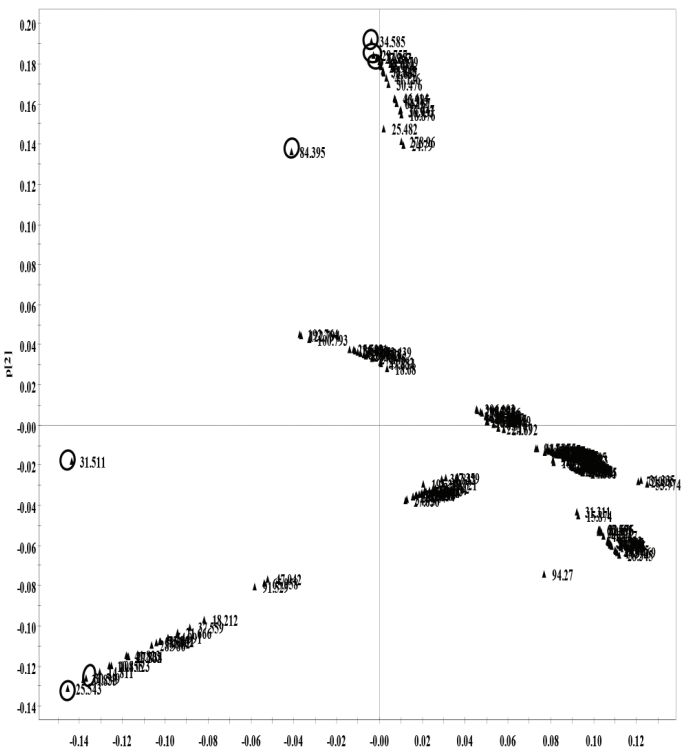

FIGURE 2. The general clustering patterns of stored raw COPT sap from fresh (F) to week 6 (W6) total proteins using principle component analysis (PCA). PCA score plot was constructed based on the optical density of protein bands from SDS-PAGE (a) $\left(\mathrm{R}^{2} \mathrm{X}=0.547\right.$, total variance $\mathrm{PC} 1, \mathrm{PC} 2=0.294)$. Loading plot (b) indicates that the cluster separation is contributed by proteins at MW 25.543, 30.549, $31.511 \mathrm{kDa}$ (W4) and MW 14.283, 29.757, 34.585 and $84.395 \mathrm{kDa}$ (W5) (circled)
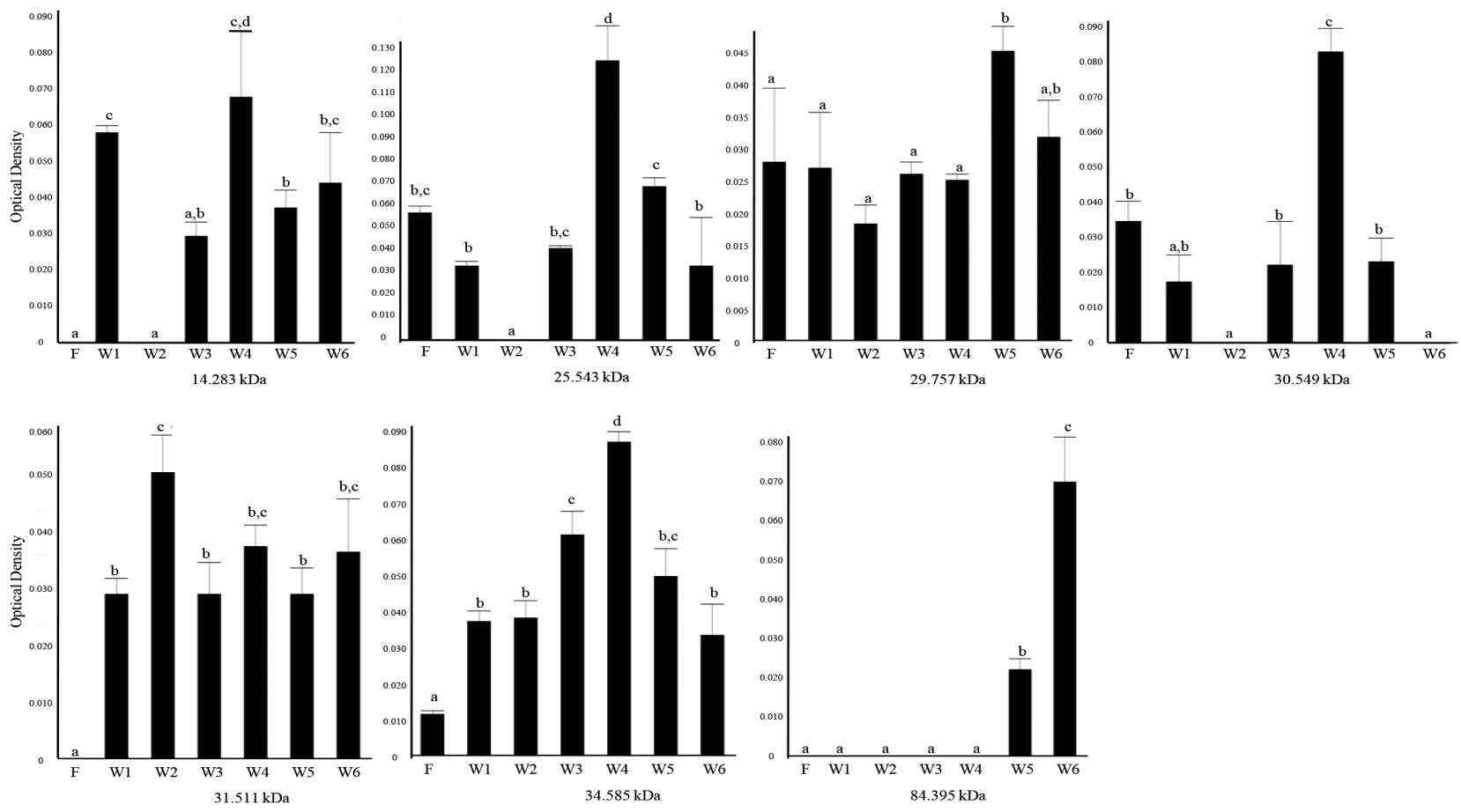

Different letters denote statistically significant using one-way ANOVA with Tukey Post-Hoc test

FIGURE 3. Protein optical density (OD) of each protein band from densitometry analysis

isoform X2 was identified. For MW $30.549 \mathrm{kDa}$, two uncharacterised proteins were found (uncharacterised protein LOC105033658 and uncharacterised protein LOC105059893 isoform X2). From MW $31.511 \mathrm{kDa}$, there were three proteins identified including UBP1- associated protein 2A-like, pentatricopeptide repeatcontaining protein At5g10690 and the probable disease resistance RPP8-like protein 2. For MW $34.585 \mathrm{kDa}$, another two proteins, putative disease resistance protein At1g50180 and pentatricopeptide repeat-containing 


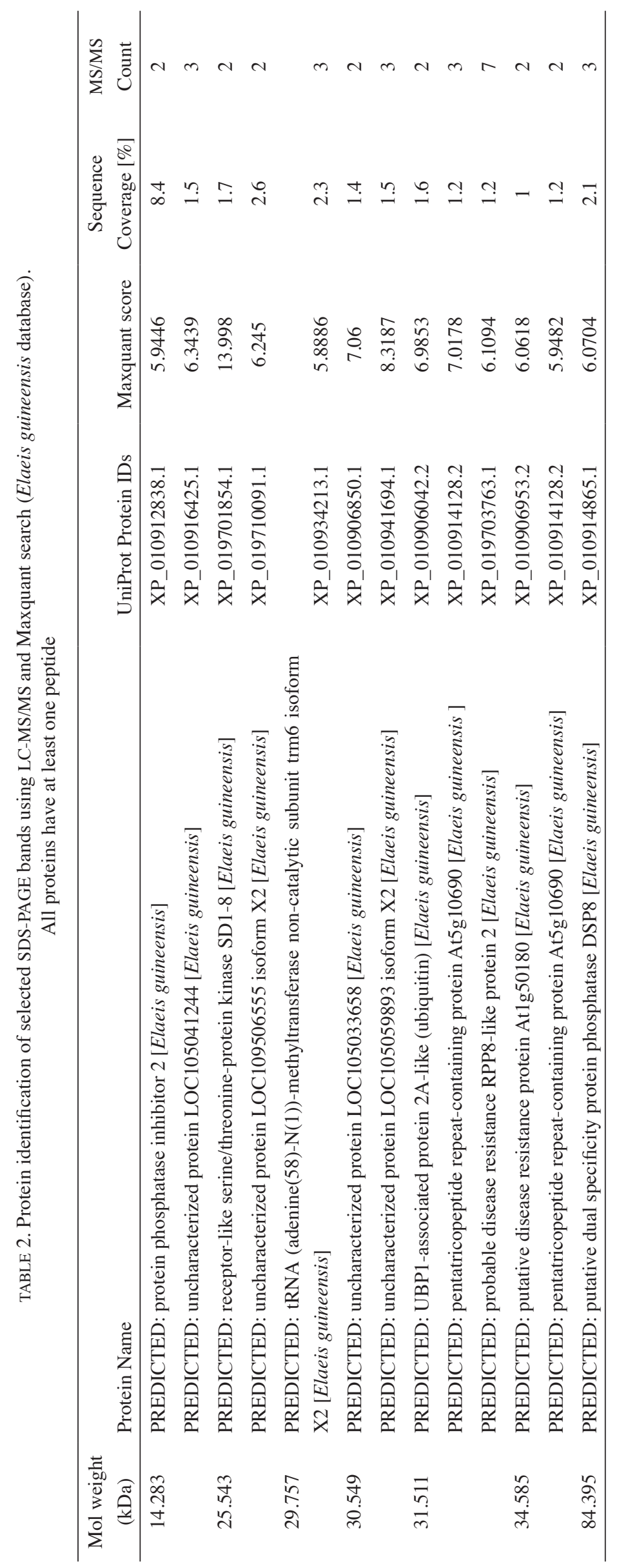


protein At5g 10690 were identified. Finally, only one protein, the putative dual specificity protein phosphatase (DSP) 8, was identified from the MW $84.395 \mathrm{kDa}$.

The combination of various semi-quantitative methods have been used previously, such as SDS-PAGE analysis, PCA, as well as densitometry analysis for protein profiling in other organisms such as in broiler chickens (Adeyemi et al. 2014), human mesenchymal stem cells (Nualkaew et al. 2017), tiger's milk mushroom (Lai et al. 2014) and in bovine and porcine gelatin (Nur Azira \& Amin 2012). However, most of these studies previously were only undertaken up to the multivariate analysis. Importantly, this study goes beyond such analysis, up to the protein identification stage using tandem mass spectrometry. Accordingly, thirteen differentially expressed proteins were successfully identified between the storage periods (Table 2 and Figure 3) which can mostly be characterised in the stress- and defense-related, disease resistance, as well as gene/protein expression processes.

\section{STRESS- AND DEFENSE-RELATED PROTEINS}

The stress- and defense-related proteins were significantly upregulated $(p<0.001)$ during the COPT storage (W1-W6), including the putative dual specificity protein phosphatase (DSP) 8, a receptor-like serine/threonine-protein kinases SD1-8 protein, phosphatase inhibitor 2 and ubiquitin (UBP1-associated protein 2A-like). Interestingly, the DSP8 protein from the $84.395 \mathrm{kDa}$ protein band was observed only at the W5 and W6 storage periods. In general, such phosphatase could be expressed as stress signals in response to the changes that have occurred in the cellular environment (physiological response) that influence posttranslational protein modification (Dickinson \& Keyse 2006; Hunter 2009; Sun \& Tonks 1994). Furthermore, this protein has been found upregulated in other plants such as Arabidopsis due to osmotic, UV and salinity stresses (Liu et al. 2012), in chestnut exposed to low temperatures (Berrocal-Lobo et al.2011) as well as in rice during periods of drought and cold stresses (Shankar et al. 2015). Thus, the increase of DSP8 found in the COPT could indicate the effects of prolonged storage conditions (more than one month) as well as the low storage temperature $\left(10^{\circ} \mathrm{C}\right)$ used.

Another stress-related protein identified, was the receptor-like serine/threonine-protein kinases SD1-8 protein. Accordingly, this protein was found from the protein band of $25.543 \mathrm{kDa}$ with a significant $(p<0.001)$ upregulation at the W4 storage period. Kinases were well recognised for their phosphorylation activities, suggesting that this protein may be specifically involved in plant regulation, energy metabolism and stress. Also, it was probable that the storage up to W4 may have induced its expression due to the storage conditions. Interestingly, this protein belongs to the receptor-like kinases (RLKs) protein family, which is known to be involved as cytokinin receptor regulating proteins related to carbohydrate metabolism (Wormit et al. 2012; Žd'árská et al. 2013).
Moreover, protein phosphatase inhibitor 2 and ubiquitin, involved in the plant defense mechanism were also identified. The phosphatase inhibitor was found to be significantly $(p<0.001)$ upregulated early during W1 and later in storage period (W4) in the MW $14.283 \mathrm{kDa}$ band. Also, this protein was previously reported found in plant and animal cells as a cellular response towards a variety of physiological and environmental stimuli (Weiser \& Shenolikar 2003), fine-tuning of plant innate immunity involving protein kinases and phosphatases (Segonzac et al. 2014). Meanwhile, the UBP1-associated protein 2A-like (ubiquitin) was found in the MW 31.511 $\mathrm{kDa}$ protein band and was significantly higher $(p<0.001)$ in all storage periods as compared to the fresh sample. Ubiquitin is responsible for the degradation of abnormal and misfolded proteins in cells via activating its ubiquitinproteasome system (UPS). Also, it is possible that prolonged storage periods may have increased protein damage in the COPT as lower protein yield was extracted from the sap of the stored COPT as compared to the fresh sample (Table 1). The upregulation of UBP1-associated protein 2A-like could also suggest its prominent role in protein homeostasis during stress.

\section{DISEASE RESISTANCE AND GENE/PROTEIN EXPRESSION RELATED PROTEIN}

Two identified proteins involved in disease resistance included the probable disease resistance RPP8-like protein 2 and the putative disease resistance protein At1g501801 and were found to be significantly $(p<0.001)$ upregulated from the protein bands of 31.511 and $34.585 \mathrm{kDa}$, respectively. Also, these proteins were reportedly involved in the defence response of plants towards the infection of bacteria, insects, viruses or fungi (Martin et al. 2003). Therefore, this suggests that upon storage, the COPT may also become infected by other microorganisms which trigger the disease-related protein to be upregulated. However, further studies in isolating and identifying the microbes from the COPT will be pertinent in understanding the role of these proteins during the occurrence of such infection.

There are also proteins involved in the gene/protein expression processes found during COPT storage, such as the pentatricopeptide repeat-containing protein At5g10690 and tRNA (adenine (58)-N (1))-methyltransferase noncatalytic subunit trm6 isoform X2. The former protein was found in both MW 31.511 and MW $34.585 \mathrm{kDa}$ bands, therefore, suggesting that it may have different isoforms differing in size. Also, this protein was significantly upregulated $(p<0.001)$ during the storage periods (W1-W6) in comparison with a fresh sample. Therefore, this protein belongs to the pentatricopeptide repeat (PPR) protein family which is responsible for plant photosynthesis, respiration, development and environmental responses (Barkan \& Small 2014). Similar PPR was also identified in Arabidopsis thaliana which functioned in endonuclease activity, RNA modification and RNA binding activity (Lurin et al. 2004). In Oryza sativa, this PPR has been upregulated as a response 


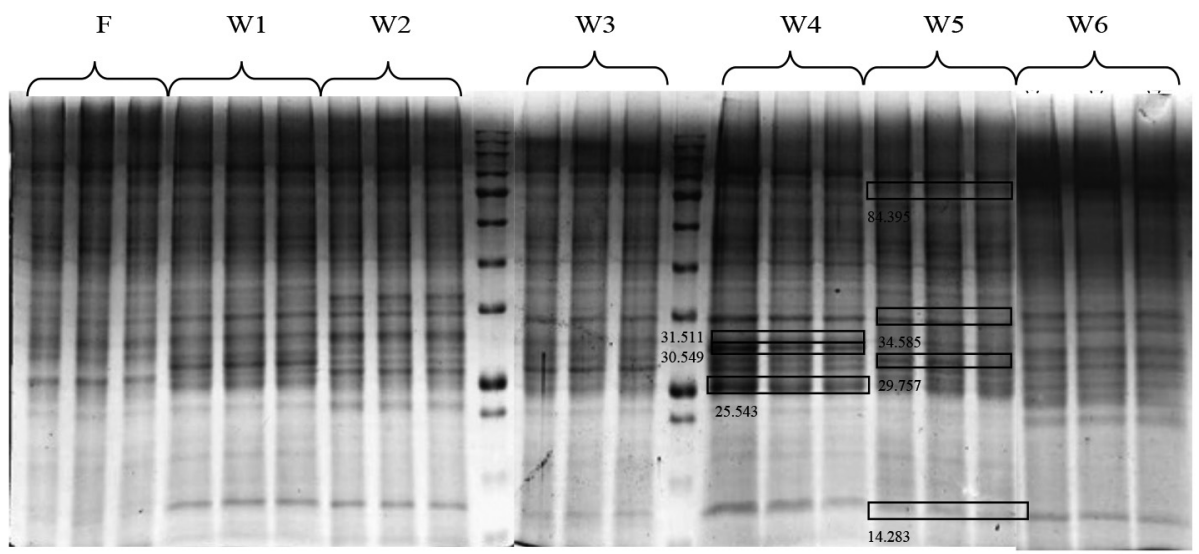

SUPPLEMENTARY FIGURE 1. SDS-PAGE patterns of stored COPT sap (raw storage condition) protein (sample F to W6) on 12.50\% acrylamide gel stained with Coomassie blue. Each lane was loaded an equal $10 \mu \mathrm{g}$ of protein concentration with three biological replicates

to stress regulation and plant development (Kushwaha et al. 2009). Meanwhile, the tRNA (adenine (58)-N (1))-methyltransferase non-catalytic subunit trm6 isoform X2 was identified in protein band MW $29.757 \mathrm{kDa}$ with significant $(p<0.001)$ upregulation at W5 observed. The tRNA (adenine(58)-N(1))-methyltransferase is important for the mitoribosomal structure to catalyse the formation of 1-methyladenosine on mitochondrial 16S ribosomal RNA (Berman et al. 2000). The increase of both proteins related to the gene/protein expression, further suggested that this process may be active during COPT storage and possibly actively expressing stress and defense-related proteins in response to the prolonged storage period, as discussed earlier.

\section{CONCLUSION}

In this study, profiling the total number of proteins from COPT sap, with emphasis on the noticeable changes during different storage conditions (up to 6 weeks of storage) was investigated. The proteins were successfully separated and quantified using SDS-PAGE and densitometry analysis, respectively. The PCA shows that proteins at W4 and W5, were farther separated and differentially expressed. Accordingly, these differentially expressed protein bands were analysed using tandem mass spectrometry, resulting in thirteen identified proteins. The proteins were categorised as a protein related to stress- and defense, disease resistance as well as a gene/protein expression. Such upregulation of these proteins signifies that prolonged storage may have introduced stresses to the COPT, resulting in protein expression changes in its sap.

\section{ACKNOWLEDGEMENTS}

We would like to acknowledge the financial support provided by the ZF-2017-001, Science fund 02-01-02SF1237 and the Ministry of Higher Education, Malaysia (MyBrain 15). The authors declare that there is no conflict or competing financial interests.

\section{REFERENCES}

Adeyemi, K.D., Mislan, N., Aghwan, Z.A., Sarah, S.A. \& Sazili, A.Q. 2014. Myofibrillar protein profile of Pectoralis major muscle in broiler chickens subjected to different freezing and thawing methods. International Food Research Journal 21(3): 1089-1093.

Al-Obaidi, J.R., Mohd-Yusuf, Y., Razali, N., Jayapalan, J.J., Tey, C.C., Md-Noh, N., Junit, S.M., Othman, R.Y. \& Hashim, O.H. 2014. Identification of proteins of altered abundance in oil palm infected with Ganoderma boninense. International Journal of Molecular Sciences 15(3): 5175-5192.

Barkan, A. \& Small, I. 2014. Pentatricopeptide repeat proteins in plants. Annual Review of Plant Biology 65: 415-442.

Berman, H.M., Westbrook, J., Feng, Z., Gilliland, G., Bhat, T.N., Weissig, H., Shindyalov, I.N. \& Bourne, P.E. 2000. The Protein Data Bank. Nucleic Acids Research 28(1): 235-242.

Berrocal-Lobo, M., Ibañez, C., Acebo, P., Ramos, A., PerezSolis, E., Collada, C., Casado, R., Aragoncillo, C. \& Allona I. 2011. Identification of a homolog of Arabidopsis DSP4(SEX4) in chestnut: Its induction and accumulation in stem amyloplasts during winter or in response to the cold. Plant Cell Environment 34(10): 1693-1704.

Bukhari, N.A., Loh, S.K., Bakar, N.A. \& Ismail, M. 2017. Hydrolysis of residual starch from sago pith residue and its fermentation to bioethanol. Sains Malaysiana 46(8): 1269-1278.

de Carvalho Silva, R., Carmo, L.S.T., Luis, Z.G., Silva, L.P., Scherwinski-Pereira, J.E. \& Mehta, A. 2014. Proteomic identification of differentially expressed proteins during the acquisition of somatic embryogenesis in oil palm (Elaeis guineensis Jacq.). Journal of Proteomics 104: 112-127.

Department of Statistic Malaysia. 2016. Selected Agriculture Indicators, Malaysia 2016. https://www.dosm.gov.my/vl/ index.php? $r=$ column $/$ cthemeByCat\&cat $=72 \& b u l \_i d=Z 3 N k h$ LSFk2VjZ5dkdUL1JQUGs4dz09\&menu_id=ZOVTZGU1UH BUT1VJMFlpaXRR0xpdz09. Accessed on May 2017.

Desiderio, C., Rossetti, D.V., Iavarone, F., Messana, I. \& Castagnola, M. 2010. Capillary electrophoresis-mass spectrometry: Recent trends in clinical proteomics. Journal of Pharmaceutical and Biomedical Analysis 53(5): 1161-1169.

Dickinson, R.J. \& Keyse, S.M. 2006. Diverse physiological functions for dual-specificity MAP kinase phosphatases. Journal of Cell Science 119(22): 4607-4615. 
Hage, D.S., Anguizola, J.A., Bi, C., Li, R., Matsuda, R. Papastavros, E., Pfaunmiller, E., Vargas, J. \& Zheng, X. 2012. Pharmaceutical and biomedical applications of affinity chromatography: Recent trends and developments. Journal of Pharmaceutical and Biomedical Analysis 69: 93-105.

Hashemi, A., Gharechahi, J., Nematzadeh, G., Shekari, F., Hosseini, S.A. \& Salekdeh, G.H. 2016. Two-dimensional blue native/SDS-PAGE analysis of whole cell lysate protein complexes of rice in response to salt stress. Journal of Plant Physiology 200: 90-101.

Hood, L. \& Rowen, L. 2013. The human genome project: Big science transforms biology and medicine. Genome Medicine 5(9): 79.

Hunter, T. 2009. Tyrosine phosphorylation: Thirty years and counting. Current Opinion in Cell Biology 21(2): 140-146.

Jahar, N.A., Pua, G., Wong, J.C., Mostapha, M., Zakaria, S., Chia, C.H. \& Jaafar, S.N.S. 2017. Utilization of core oil palm trunk waste to methyl levuinate: Physical and chemical characterizations. Waste and Biomass Valorization pp. 1-6.

Jeffery Daim, L.D., Ooi, T.E.K., Ithnin, N., Mohd Yusof, H., Kulaveerasingam, H., Abdul Majid, N. \& Karsani, S.A. 2015. Comparative proteomic analysis of oil palm leaves infected with Ganoderma boninense revealed changes in proteins involved in photosynthesis, carbohydrate metabolism, and immunity and defense. Electrophoresis 36(15): 1699-1710.

Kushwaha, H.R., Singh, A.K., Sopory, S.K., Singla-Pareek, S.L. \& Pareek, A. 2009. Genome wide expression analysis of CBS domain containing proteins in Arabidopsis thaliana (L.) Heynh and Oryza sativa L. reveals their developmental and stress regulation. BioMed. Central Genomics 10: 200.

Lai, W.H., Leo, T.K., Zainal, Z. \& Daud, F. 2014. Preliminary proteomic characterisation of primodia and vegetative dikaryotic mycelial cells from Tiger's milk mushroom (Lignosus rhinocerus). Sains Malaysiana 43(8): 1133-1138.

Liu, B., Fan, J., Zhang, Y., Mu, P., Wang, P., Su, J., Lai, H., Li, S., Feng, D., Wang, J. \& Wang, H. 2012. OsPFA-DSP1, a rice protein tyrosine phosphatase, negatively regulates drought stress responses in transgenic tobacco and rice plants. Plant Cell Reports 31(6): 1021-1032.

Lurin, C., Andres, C., Aubourg, S., Bellaoui, M., Bitton, F., Bruyere, C., Caboche, M., Debast, C., Gualberto, J., Hoffmann, B., Lecharny, A., Le Ret, M., Martin-Magniette, M.L., Mireau, H., Peeters, N., Renou, J.P., Szurek, B., Taconnat, L. \& Small, I. 2004. Genome-wide analysis of Arabidopsis pentatricopeptide repeat proteins reveals their essential role in organelle biogenesis. The Plant Cell 16(8): 2089-2103.

Malaysia Palm Oil Board. Malaysia Palm Oil Industry: A report. http://www.palmoilworld.org/about _malaysian-industry. html. Accessed on 20 October 2016.

Martin, G.B., Bogdanove, A.J. \& Sessa, G. 2003. Understanding the functions of plant disease resistance proteins. Annual Review of Plant Biology 54(1): 23-61.

Mostapha, M., Jahar, N.A., Chin, S.X., Jaafar, S.N.S., Zakaria, S., Aizat, W.M. \& Azizan, K.A. 2016. Effect of zeolite catalyst on sugar dehydration for 5 Hydroxymethylfurfural synthesis. American Institute of Physics Conference Proceedings 1784(1): 040026.

Mostapha, M., Jahar, N.A., Zakaria, S., Aizat, W.M., Azizan, K.A. \& Jaafar, S.N.S. 2017. Metabolite profiling of core oil palm trunk (COPT) sap: The effects of different storage durations, conditions and temperatures. Journal of Oil Palm Research 30(1): 111-120.
Nualkaew, S., Saelim, H., Tiwawech, D., Parvez, T.P.I. \& Phongdara, A. 2017. Role of cytochrome P450 monooxygenase in the bioactivation of aflatoxin B1. Sains Malaysiana 46(9): 1499-1503.

Nur Azira, T. \& Amin, I. 2012. Differentiation of bovine and porcine gelatins in processed products via sodium dodecyl sulphate-polyacrylamide gel electrophoresis (SDS PAGE) and principal component analysis (PCA) techniques. International Food Research Journal 19(3): 1175-1180.

Segonzac, C., Macho, A.P., Sanmartín, M., Ntoukakis, V., Sánchez-Serrano, J.J. \& Zipfel, C. 2014. Negative control of BAK1 by protein phosphatase 2A during plant innate immunity. The European Molecular Biology Organization Journal 33: 2069-2079.

Shankar, A., Agrawal, N., Sharma, M., Pandey, A. \& Pandey, G.K. 2015. Role of protein tyrosine phosphatases in plants. Current Genomics 16(4): 224-236.

Smith P., Bustamante, M., Ahammad, H., Clark, H., Dong, H., Elsiddig, E.A., Haberl, H., Harper, R., House, J., Jafari, M., Masera, O., Mbow, C., Ravindranath, N.H., Rice, C.W., Robledo Abad, C., Romanovskaya, A., Sperling, F. \& Tubiello, F. 2014. Agriculture, forestry and other land use (AFOLU). In Climate Change 2014: Mitigation of Climate Change. Contribution of Working Group III to the Fifth Assessment Report of the Intergovernmental Panel on Climate Change, edited by Edenhofer, O., Pichs-Madruga, R., Sokona, Y., Farahani, E., Kadner, S., Seyboth, K., Adler, A., Baum, I., Brunner, S., Eickemeier, P., Kriemann, B., Savolainen, J., Schlömer, S., von Stechow, C., Zwickel, T. \& Minx, J.C. Cambridge: Cambridge University Press.

Sun, H. \& Tonks, N.K. 1994. The coordinated action of protein tyrosine phosphatases and kinases in cell signaling. Trends in Biochemicals Science 19(11): 480-485.

Wang, W., Vignani, R., Scali, M. \& Cresti, M. 2006. A universal and rapid protocol for protein extraction from recalcitrant plant tissues for proteomic analysis. Electrophoresis 27(13): 2782-2786.

Weiser, D.C. \& Shenolikar, S. 2003. Use of protein phosphatase inhibitors. Curr. Protoc. Mol. Biol. 62(1): 18.10.1-18.10.13.

Wormit, A., Butt, S.M., Chairam, I., McKenna, J.F., Nunes-Nesi, A., Kjaer, L., O’Donnelly, K., Fernie, A.R., Woscholski, R., Barter, M.C. \& Hamann, T. 2012. Osmosensitive changes of carbohydrate metabolism in response to cellulose biosynthesis inhibition. Plant Physiology 159(1): 105-117.

Yamada, H., Tanaka, R., Sulaiman, O., Hashim, R., Hamid, Z.A.A., Yahya, M.K.A., Kosugi, A., Arai, T., Murata, Y., Nirasawa, S., Yamamoto, K., Ohara, S., Yusof, M.N.M., Ibrahim, W.A. \& Mori, Y. 2010. Old oil palm trunk: A promising source of sugars for bioethanol production. Biomass and Bioenergy 34: 1608-1613.

Žd'árská, M., Zatloukalová, P., Benítez, M., Šedo, O., Potěšil, D., Novák, O., Svačinová, J., Pešek, B., Malbeck, J., Vašíčková, J., Zdráhal, Z. \& Hejátko, J. 2013. Proteome analysis in Arabidopsis reveals shoot- and root-specific targets of cytokinin action and differential regulation of hormonal homeostasis. Plant Physiology 161(2): 918-930.

Marhaini Mostapha, Noorhasmiera Abu Jahar,

Sarani Zakaria \& Sharifah Nabihah Syed Jaafar*

Bioresources and Biorefinary Laboratory

Faculty of Science and Technology

Universiti Kebangsaan Malaysia 
43600 UKM Bangi, Selangor Darul Ehsan Malaysia

Kamalrul Azlan Azizan \& Wan Mohd Aizat Institute of Systems Biology (INBIOSIS)

Universiti Kebangsaan Malaysia 43600 UKM Bangi, Selangor Darul Ehsan Malaysia
*Corresponding authors; email: nabihah@ukm.edu.my

Received: 4 October 2017

Accepted: 18 January 2018 